\title{
ABSTRAK \\ PENGARUH PERTUMBUHAN EKONOMI, INFRASTRUKTUR, PENGANGGURAN TERHADAP TINGKAT KEMISKINAN DI KABUPATEN MALUKU TENGGARA
}

\author{
Muhamad Taher Jamco, Jurusan Administrasi Bisnis \\ STIA Darul Rachman Tual, taher_jamco@yahoo.com
}

\begin{abstract}
Penelitian ini menggunakan data sekunder tahun 2009-2013 di Kabupaten Maluku Tenggara dengan metode analisis deskriptif dan kuantitatif, dengan pendekatan alat analisis regresi berganda. Adapun data yang digunakan dalam penelitian ini merupakan data runtut waktu (time series) selama periode 2009 sampai 2013. Analisis ini digunakan untuk menganalisis hubungan antara kemiskinan (dependen variabel) maupun pertumbuhan ekonomi, infrastruktur, dan pengangguran (independen variabel). Hasil penelitian menunjukkan bahwa kenaikan pertumbuhan ekonomi sebesar $1 \%$, maka berpengaruh terhadap penurunan tingkat kemiskinan sebesar 1,093238 satuan persen yang berarti hubungan antara kedua variabel negatif. Hasil penelitian infrastruktur terhadap kemiskinan juga negatif, karena kenaikan infrastruktur 1\%, maka akan berpengaruh terhadap penurunan tingkat kemiskinan sebesar 0,098056 satuan persen di Kabupaten Maluku Tenggara. Kemudian pengangguran berpengaruh positif dan signifikan terhadap tingkat kemiskinan, artinya bahwa terjadi peningkatan pengangguran $1 \%$ akan berpengaruh terhadap peningkatan kemiskinan sebesar 0,102886 satuan persen di Kabupaten Maluku Tenggara.
\end{abstract}

Kata kunci: kemiskinan, pertumbuhan ekonomi, infrastruktur

\section{ABSTRACT \\ THE INFLUENCE OF ECONOMIC GROWTH , INFRASTRUCTURE, UNEMPLOYMENT ON THE LEVEL OF POVERTY IN THE DISTRICT OF SOUTHEASTERN THE MOLUCCAS}

This study using data secondary in 2009-2013 in the south-east Moluccas with a descriptive analysis and quantitative, with the approach of the regression analysis worship of idols. The data used in this research are date time (time) for a series of 2009 until 2013.This analysis used to analyze the link between poverty (dependent) variable and economic growth, the infrastructure, and high unemployment (independent variable). 
The results of research shows that the increase in economic growth at 1 percent, the impact on the decreasing level of poverty 1,093238 unit percent which means relations between the two variable negative. The results of research infrastructure to poverty is also negative, because the increase in infrastructure 1 percent, it will impact on the decreasing level of poverty 0,098056 unit percent in the district southeast of the Moluccas. And unemployment affect positive and significant impact on the poverty level, that means that an increase was 1 percent unemployment rate would affect on the increasing poverty of 0,102886 unit percent in the district southeast of the Moluccas

Keywords: poverty, economic growth, infrastructure

Kemiskinan merupakan persoalan yang penuh kontroversial, maka cara penanggulangan kemiskinan pun membutuhkan analisis yang tepat, melibatkan semua komponen permasalahan, dan diperlukan strategi penanganan yang tepat, berkelanjutan dan tidak bersifat temporer. Sejumlah variabel dapat dipakai untuk melacak persoalan kemiskinan, dan dari variabel ini dihasilkan serangkaian strategi dan kebijakan penanggulangan kemiskinan yang tepat sasaran dan berkesinambungan.

Kenyataan yang terjadi adalah masih banyak masalah ekonomi dan sosial yang dihadapi antara lain, masih tingginya tingkat kemiskinan yang terjadi di Kabupaten Maluku Tenggara, sehingga merupakan masalah yang sangat fundamental dan mengkhawatirkan, hal ini tercermin jumlah penduduk miskin yang tinggi dan bervariasi jumlahnya (tabel 1). Pada tahun 2009 jumlah orang miskin 55.890 atau $41,69 \%$ dari jumlah penduduk, tahun 2010 jumlah orang miskin 63.480 atau 46,32\%, tahun 2011 jumlah orang miskin 82.542 atau 57,23\%. Pada tahun 2012 jumlah orang miskin menurun 75.680 atau $51,42 \%$ dan tahun 2013 dengan adanya pergeseran penduduk hampir miskin menjadi miskin sehingga terjadi peningkatan jumlah orang miskin 88.176 atau $58,72 \%$ dari jumlah penduduk Kabupaten Maluku Tenggara. Tingginya tingkat kemiskinan dari tahun ke tahun menggambarkan beratnya tantangan dan masalah pembangunan ekonomi dan sosial yang dihadapi Kabupaten Maluku Tenggara.

Perkembangan pertumbuhan ekonomi secara fluktuasi ini disebabkan 
karena belum adanya regulasi pemerintah daerah yang mengatur pengolahan perikanan secara efektif. Kenyataan ini merupakan permasalahan yang menyebabkan Kabupaten Maluku Tenggara selalu tertinggal jika dibandingkan kabupaten/kota lain yang ada di Provinsi Maluku. Pembangunan infrastruktur sangat ditentukan oleh kemampuan keuangan daerah dan kemauan dari para pembuat kebijakan. Pengeluaran publik merupakan salah satu faktor yang dapat mempercepat pertumbuhan ekonomi yang pada akhirnya akan meningkatkan pendapatan dan mengurangi jumlah penduduk yang hidup di bawah garis kemiskinan. Menurut Salim (2006) mestinya, pemerintah memprioritaskan pembangunan jalan kabupaten karena jalan itu akan membuka akses transportasi dan informasi ke berbagai pelosok, sehingga perbaikan dan pembangunan sarana dan prasarana jalan, jembatan dan irigasi dapat memberikan dampak tidak langsung bagi peningkatan produktifitas dan pendapatan masyarakat miskin yang sebagian besar bekerja di sektor pertanian. Menurut Fan (2003) investasi publik dalam infrastruktur fisik dibutuhkan untuk meningkatkan produktifitas dan untuk mencapai pertumbuhan perekonomian dalam jangka panjang.

Fakta menunjukkan bahwa, berbagai persoalan kemiskinan yang sedemikian pelik ini akan mudah dituntaskan dengan adanya program dan kebijakan pemerintah daerah. Adanya progam dan kebijakan ini diharapkan mampu memberikan kesempatan kepada pelaku ekonomi di daerah untuk dapat berkontribusi lebih efektif dan berpartisipasi dalam membangun, serta memberikan kemudahan dalam melakukan kegiatan ekonomi yang nantinya dapat mendorong ekonomi masyarakat miskin, agar kebijakan penanggulangan kemiskinan yang harus memihak kepada rakyat miskin.

Berdasarkan uraian pada latar belakang yang dikemukakan di atas, ternyata pengaruh aspek ekonomi dan sosial terhadap tingkat kemiskinan di Kabupaten Maluku Tenggara tergolong masih tinggi. Oleh sebab itu, yang menjadi permasalahan dalam penelitian ini adalah belum adanya kajian mengenai faktor-faktor yang mempengaruhi tingkat kemiskinan di Maluku Tenggara. 


\section{METODE PENELITIAN}

Penelitian ini menggunakan pendekatan metode analisis deskriptif dan kuantitatif dengan alat analisis regresi berganda. Adapun data yang digunakan dalam penelitian ini adalah data runtut waktu (time series) selama periode 2009 sampai 2013. Menurut Gujarati (1999: 124) tujuan dari model regresi adalah sebagai berikut: pertama, untuk mengestimasi nilai rata-rata variabel tak bebas dan nilai rata-rata variabel bebas tertentu. Kedua, untuk menguji hipotesis mengenai sifat ilmiah ketergantungan hipotesis sebagaimana yang disarankan oleh teori ekonomi, dan ketiga, untuk memprediksi atau meramalkan nilai ratarata variabel tak bebas dan nilai rata-rata variabel bebas tertentu. Kemudian pada bagian lain, analisis korelasi adalah mengukur kekuatan (strength) atau tingkat hubungan (degree of association) antara dua variabel. Jadi analisis regresi dan korelasi secara konseptual sangat berbeda. Tingkat hubungan antara dua variabel disebut pula dengan korelasi sederhana (simple correlation), sementara tingkat hubungan antara tiga variabel disebut dengan korelasi berganda (multiple correlation).

Model penelitian ini mempertimbangkan hubungan teoritis antarvariabel penjelas, maka penelitian tentang faktor-faktor yang berpengaruh terhadap tingkat kemiskinan di Kabupaten Maluku Tenggara

\section{HASIL PENELITIAN}

Analisis dalam penelitian ini adalah analisis regresi linier berganda. Analisis ini digunakan untuk mengetahui pengaruh pertumbuhan ekonomi, infrastruktur, dan tingkat pengangguran terhadap tingkat kemiskinan di Kabupaten Maluku Tenggara. Adapun bentuk persamaan regresinya adalah:

Tabel 1. Hasil Regresi Berganda dengan Metode OLS

Dependent Variable: TK

Method: Least Squares

Date: 05/18/13 Time: 19:05

Sample: 2000:1 2013:4

Included observations: 56

\begin{tabular}{rrrrr}
\hline Variable & Coefficient & Std. Error & t-Statistic & Prob. \\
\hline C & 3.437813 & 4.062204 & 0.846292 & 0.4013 \\
PE & -1.093238 & 0.522305 & -2.093102 & 0.0412 \\
IS & -0.098056 & 0.048824 & -2.008357 & 0.0463 \\
TP & 0.102886 & 0.052655 & 1.953964 & 0.0506 \\
\hline R-squared & 0.722244 & Mean dependent var & & 5.010536
\end{tabular}




\begin{tabular}{lrll} 
Adjusted R-squared & 0.720720 & S.D. dependent var & 23.19930 \\
S.E. of regression & 22.32780 & Akaike info criterion & 9.118292 \\
Sum squared resid & 25923.60 & Schwarz criterion & 9.262960 \\
Log likelihood & -251.3122 & F-statistic & 10.45909 \\
Durbin-Watson stat & 1.517968 & Prob(F-statistic) & 0.003060 \\
\hline
\end{tabular}

Sumber: Hasil Olah Data Regresi Berganda, 2013.

Secara matematis hasil dari

analisis regresi linier berganda tersebut dapat ditulis sebagai berikut:

$$
Y=3,437813 \text { - 1,093238 PE - }
$$

\section{0,098056 IS + 0,102886 TP}

Pada persamaan di atas ditunjukkan pengaruh variabel independen terhadap variabel dependen. Arti dari koefisien regresi tersebut adalah.

1. $\boldsymbol{\beta}_{0}=\mathbf{3 , 4 3 7 8 1 3}$ artinya, rata-rata tingkat kemiskinan jika tidak dipengaruhi oleh pertumbuhan ekonomi, infrastruktur, dan tingkat pengangguran, maka tingkat kemiskinan di Kabupaten Maluku Tenggara sebesar 3,437813 persen.

2. $\beta_{1}=\mathbf{- 1 , 0 9 3 2 3 8}$ Artinya apabila pertumbuhan ekonomi $\left(\mathrm{X}_{1}\right)$ mengalami kenaikan sebesar 1 persen, maka tingkat kemiskinan di Kabupaten Maluku Tenggara akan turun sebesar 1,093238 persen dengan asumsi variabel lain adalah konstan (ceteris paribus).

3. $\boldsymbol{\beta}_{2}=\mathbf{- 0 , 0 9 8 0 5 6}$ Artinya apabila infrastruktur $\left(\mathrm{X}_{2}\right) \quad$ mengalami kenaikan sebesar 1 persen, maka tingkat kemiskinan di Kabupaten Maluku Tenggara akan turun sebesar 0,098056 persen dengan asumsi variabel lain adalah konstan (ceteris paribus).

4. $\boldsymbol{\beta}_{3}=\mathbf{0 , 1 0 2 8 8 6}$ Artinya apabila tingkat pengangguran $\left(\mathrm{X}_{3}\right)$ mengalami kenaikan sebesar 1 persen, maka tingkat kemiskinan di Kabupaten Maluku Tenggara akan naik sebesar 0,102886 persen dengan asumsi variabel lain adalah konstan (ceteris paribus).

\section{PEMBAHASAN}

1. Pengujian $\mathbf{R}^{2} \quad$ (Koefisien Determinasi): $\mathrm{R}^{2} \quad$ (Koefisien Determinasi) ini digunakan untuk mengetahui seberapa besar kemampuan variabel independen dalam menjelaskan secara komprehensif terhadap variabel dependen. Nilai $\mathrm{R}^{2}$ (Koefisien Determinasi) mempunyai range antara 0-1. Semakin besar $\mathrm{R}^{2}$ 
mengindikasikan semakin besar kemampuan variabel independen dalam menjelaskan variabel dependen. Hasil dari regresi dengan metode OLS diperoleh $\mathrm{R}^{2}$ (Koefisien Determinasi) sebesar 0,722 artinya variabel dependen dalam model yaitu tingkat kemiskinan di Kabupaten Maluku Tenggara dijelaskan oleh variabel independen yaitu pertumbuhan ekonomi, infrastruktur, dan tingkat pengangguran sebesar 72,2 persen, sedangkan sisanya sebesar 27,8 persen dijelaskan oleh faktor lain di luar model.

2. Analisis ekonomi: Setelah dilakukan analisis statistik dan ekonometrika, sesuai tujuan penelitian maka dilakukan analisis secara ekonomi dengan memberikan uraian hasil estimasi ditekankan pada kesesuaian teori dan penelitian yang pernah dilakukan sebelumnya.

3. Pengaruh pertumbuhan ekonomi terhadap tingkat kemiskinan: Hasil analisis regresi linier berganda menunjukkan bahwa pertumbuhan ekonomi berpengaruh negatif dan signifikan terhadap tingkat kemiskinan, di mana hasil koefisien nilai korelasi sebesar $-1,093238$ artinya bahwa jika pertumbuhan ekonomi mengalami peningkatan sebesar 1persen, maka tingkat kemiskinan akan turun sebesar 1,093238. Hal ini berarti pertumbuhan ekonomi merupakan salah satu faktor yang berpengaruh terhadap penurunan tingkat kemiskinan di Kabupaten Maluku Tenggara. walaupun tidak signifikan namun peningkatan pertumbuhan ekonomi tetap memberi sumbangan terhadap penurunan kemiskinan. Penelitian ini sejalan dengan penelitian yang pernah dilakukan oleh Dollar dan Kraay (2002), Balisacan dkk. (2003) serta Tambunan (2005) yang menyimpulkan bahwa meningkatnya kesejahteraan dan pemerataan distribusi pendapatan masyarakat pada akhirnya menurunkan tingkat kemiskinan

4. Pengaruh infrastruktur terhadap tingkat kemiskinan: Hasil analisis regresi linier berganda menunjukkan bahwa infrastruktur berpengaruh negatif dan signifikan terhadap tingkat kemiskinan, di mana hasil 
koefisien nilai regresi sebesar 0,098056 artinya bahwa jika infrastruktur mengalami peningkatan 1 persen maka tingkat kemiskinan akan turun sebesar 0,098056. Hal ini berarti terjadi peningkatan infrastruktur, akan berpengaruh terhadap penurunan tingkat kemiskinan di Kabupaten Maluku Tenggara. Sejalan dengan penelitian yang dilakukan Kwon (2003) dengan penelitian keterkaitan antara pembangunan infrastruktur jalan terhadap penurunan angka kemiskinan dengan menggunakan data panel tingkat provinsi di Indonesia selama periode 1976-1996 dengan menggunakan analisis splitting sample. Hasil penelitian dapat disimpulkan bahwa tingkat kemiskinan sangat sensitif terhadap investasi jalan. Ketika investasi jalan naik 1 persen maka kemiskinan menurun $0,3 \%$, jadi peranan jalan terhadap pengentasan kemiskinan sangat penting.

\section{Pengaruh pengangguran terhadap} tingkat kemiskinan: Hasil analisis regresi linier berganda menunjukkan bahwa tingkat pengangguran berpengaruh positif dan signifikan sebesar koefisien regresi 0,102886 terhadap tingkat kemiskinan di Kabupaten Maluku Tenggara Hal ini berarti, jika terjadi kenaikan pengangguran sebesar 1 persen, maka akan berpengaruh terhadap peningkatan kemiskinan sebesar 0,102886, di Kabupaten Maluku Tenggara. Dengan demikian penelitian ini sejalan dengan studi Fornby dkk. (2000). Bahwa pengangguran berhubungan positif dengan kemiskinan di Amerika Serikat.

\section{KESIMPULAN}

Berdasarkan hasil pembahasan dan analisis yang dilakukakan pada penelitian ini, maka faktor-faktor yang berpengaruh terhadap tingkat kemiskinan di Kabupaten Maluku Tenggara selama tahun 2009-2013 adalah pertumbuhan ekonomi, pertumbuhan infrastruktur dan tingkat pertumbuhan pengangguran dengan penjabaran sebagai berikut.

1. Berdasarkan hasil olah data diperoleh nilai $\mathrm{t}_{\text {-statistik }}=-2,093<\mathrm{t}_{\text {-tabel }}-1,671$, maka ada pengaruh secara negatif dan signifikan variabel pertumbuhan 
ekonomi terhadap variabel tingkat kemiskinan di Kabupaten Maluku Tenggara. Hal ini ditunjukkan dengan koefisien regresi $\beta_{1}=$ 1,093238. Artinya apabila pertumbuhan ekonomi mengalami kenaikan sebesar 1 persen, maka tingkat kemiskinan di Kabupaten Maluku Tenggara akan turun sebesar 1,093238 persen dengan asumsi variabel lain adalah konstan (ceteris paribus).

2. Berdasarkan hasil olah data diperoleh nilai $\mathrm{t}_{\text {-statistik }}=-2,008<\mathrm{t}_{\text {-tabel }}-1,671$, maka disimpulkan bahwa ada pengaruh secara negatif dan signifikan variabel pertumbuhan infrastruktur terhadap variabel tingkat kemiskinan di Kabupaten Maluku Tenggara. Hal ini ditunjukkan dengan nilai koefisien regresi $\beta_{2}=-0,098056$. Artinya apabila tingkat pertumbuhan infrastruktur mengalami kenaikan sebesar 1 persen, maka tingkat kemiskinan di Kabupaten Maluku Tenggara akan turun sebesar 0,098056 persen dengan asumsi variabel lain adalah konstan (ceteris paribus).
3. Berdasarkan hasil olah data diperoleh nilai $\mathrm{t}_{\text {-statistik }}=1,954>\mathrm{t}_{\text {-tabel }} 1,671$, maka disimpulkan bahwa ada pengaruh secara positif dan signifikan variabel tingkat pertumbuhan pengangguran terhadap variabel tingkat kemiskinan. Hal ini ditunjukkan dengan nilai koefisien regresi $\beta_{3}=0,102886$ Artinya apabila tingkat pertumbuhan pengangguran mengalami kenaikan sebesar 1 persen, maka tingkat kemiskinan di Kabupaten Maluku Tenggara akan naik sebesar 0,102886 persen dengan asumsi variabel lain adalah konstan (ceteris paribus).

\section{DAFTAR PUSTAKA}

Agenor, Richard and Pierre. 2004. Unemployment-Poverty TradeOffs. The World Bank. Washington DC

Badan Pusat Statistik (BPS) Kabupaten Maluku Tenggara, Maluku Tenggara Dalam Angka Tahun 2007

Balisacan, Arsenio M, Ernesto $\mathrm{M}$ and Abuzar Asra. 2003. "Revisiting Growth and Poverty Reduction in Indonesia: What Do Subnational Data Show?". BIES Australian National University Project. Vol. 39 No. 3, hal. 329-351

Boediono. 1999. Teori Pertumbuhan Ekonomi. Edisi Pertama. Cetakan Keenam. BPFE. Yogyakarta 
Dollar, David and Aart Kraay. 2002. "Growth is Good for the Poor". Journal of Economic Growth. Vol.7 No, hal.195-225

Fan, Shenggen. 2003. "Public Investment and Poverty Reduction Case Studies From Asia and Implication For Latin America". Seminario Internacional.

Tendencias Y Desafios En Gestion Del Gasto Publiko Para El Desarrollo Agricola Y Rural En America Latina Y EI Caribe

Fornby, Jhon P, Gary A. Hoover and Hoseong Kim. 2000. "Economic Growth and Poverty in The United States: Comparisons of Estimates upon Official Poverty Statistics and Sen's Index of Poverty". Seminar. Culverhouse College of Commerce and Business Administration The University of Alabama. Tuscaloosa

Gie, Kwik Kian. 2002. "Pembiayaan Pembangunan Infrastruktur dan Permukiman". Materi Kuliah. disampaikan pada Studium General Institut Teknologi Bandung

Gujarati, Damodar. 1999. Basic Econometrics, Fourth Edition. McGraw-Hill. International Editions. Economics Series

Kuncoro, Mudrajad. 2006. Ekonomika Pembangunan. Teori, Masalah, dan Kebijakan, Edisi Keempat. UPP STIM YKPN Yogyakarta

Kwon, Eunkyung. 2003. "Infrastructure, Growth and Poverty Reduction in Indonesia: A Croos-Sectional Analysis". Paper. Asia Development Bank, hal.1-27

Mankiw, N. Gregory. 2000. Pengantar Ekonomi. Edisi ke 1, Jilid 2.
Erlangga. Jakarta

Salim, Emil. 2006. Perbaikan Infrastruktur Bisa Atasi Kemiskinan. Artikel. Media Indonesia Online

Suryahadi, Asep, Daniel Suryadarma dan Sudarno Sumarto. 2006. "Economic Growth and Poverty Reduction in Indonesia: The Effect of Location and Sectoral Components of Growth". Working Paper. SMERU Research Institute. Jakarta

Tambunan, Tulus. 2005. "Linkages Between Macroeconomic Reform Policies, Shocks, and Poverty Reduction: The Indonesian Case". Artikel. LP3E-KADIN Indonesia 